\title{
Oral Mucosal Lesions among Prisoners in Central Prison, Chennai, India
}

\author{
${ }^{1}$ Benley George, ${ }^{2}$ Minimol K Johny, ${ }^{3} \mathrm{~T}$ Aby Mathew
}

\begin{abstract}
Background: Oral health status of prisoners has been an area of concern worldwide. The prison population is unique in nature because of the complexities of their psychological, social and behavioral aspects. Limited oral healthcare facilities in prison settings have resulted in neglect of oral health among prisoners.
\end{abstract}

Aim: The present study aims to assess oral mucosal lesions among prisoners in Central Prison, Chennai.

Materials and methods: A cross-sectional epidemiological survey was conducted in Central Prison, Puzhal, Chennai. The study population consisted of 1060 prisoners from three divisions of the Central Prison. Oral mucosal lesions among the prisoners were assessed by a single investigator according to World Health Organization (WHO) specifications.

Results: The present study shows that among the study subjects, $37.7 \%$ of males and $17.1 \%$ of females developed oral mucosal lesions. The prevalence of smokers melanosis was $27.6 \%$ among males and $8.6 \%$ among females. The prevalence of oral mucosal lesions was found to be highest in study subjects of 55 years and above.

Conclusion: A large proportion of the study subjects had oral mucosal lesions. Oral mucosal lesions like oral submucosis fibrosis, smokers palate and smokers melanosis was found to be common among males than females. Oral healthcare facilities should be incorporated in prison settings which would intercept the progress of oral mucosal lesions.

Keywords: Chennai, Oral lesions, Oral submucous fibrosis, Prisoners.

How to cite this article: George B, Johny MK, Mathew TA. Oral Mucosal Lesions among Prisoners in Central Prison, Chennai, India. Int J Experiment Dent Sci 2015;4(2):77-79.

\footnotetext{
${ }^{1}$ Reader and Head, ${ }^{2}$ Senior Lecturer, ${ }^{3}$ Professor

${ }^{1}$ Department of Public Health Dentistry, Pushpagiri College of Dental Sciences, Thiruvalla, Kerala, India

${ }^{2}$ Department of Conservative Dentistry and Endodontics Pushpagiri College of Dental Sciences, Thiruvalla, Kerala, India

${ }^{3}$ Department of Prosthodontics and Crown and Bridge Pushpagiri College of Dental Sciences, Thiruvalla, Kerala, India

Corresponding Author: Benley George, Reader and Head, Department of Public Health Dentistry, Pushpagiri College of Dental Sciences, Thiruvalla, Kerala, India, Phone: 9745015511, e-mail: georgebenley@yahoo.co.in
}

\section{Source of support: Nil}

Conflict of interest: None

\section{INTRODUCTION}

Prison is a correctional institution where persons are confined while on trial or for punishment. The health of prisoners is of great concern particularly, because the number of persons under the jurisdiction of correction systems, including those on probation or parole, continues to increase dramatically. ${ }^{1}$ A survey conducted among 124 males prisoners in southern Norway revealed a decayed missing and filled teeth (DMFT) of 18.8 for those below 30 years of age and a DMFT of 21.7 for 30 years and above. ${ }^{2}$ A study among prisoners at risk of human immunodeficiency virus (HIV) in Mexico showed that none of the prisoners were HIV positive. Oral mucosal lesions were found in $94 \%$ of the prisoners. A higher frequency of pigmented lesions was found among subjects with history of marijuana use. A lower prevalence of fordyce's spot was observed among subjects with history of heroin abuse than in nonuser's. ${ }^{3}$

Improving the oral health of inmates is a challenging task. As service users, inmates are more likely to have disadvantaged backgrounds or come from localities with increased levels of social exclusion, with a high proportion of them being unemployed prior to sentencing. As a consequence, oral health requirements of prisoners at admission may be particularly high with a significant amount of unmet treatment needs. Dental problems may be severe, sometimes associated with drug abuse. ${ }^{4}$ Currently, there has been dearth of data pertaining to oral mucosal lesions among prisoners. The aim of the study was to assess oral mucosal lesions among prisoners in Central Prison, Chennai, India.

\section{MATERIALS AND METHODS}

A cross-sectional epidemiological survey was conducted in Central Prison, Chennai, India which is one of the largest prisons in Asia. The study population consisted of 1060 prisoners from three divisions of the Central Prison in Chennai, during the period of April to May 2009. An Ethical clearance was obtained prior to the start of the study. Prior permission and approval for the conduct of the study was obtained. All subjects, regardless of the 
duration of time already spent in prison, were given oral information emphasizing the purpose of the study. Subjects who were willing to participate were included the study.

A single investigator assessed the oral cavity of each subject. Dental examinations were done under natural light by means of mouth mirror and a periodontal probe which conform to World Health Organization (WHO) specifications. ${ }^{5}$ The investigator was trained and calibrated through a series of clinical sessions prior to the start of the study. The intraexaminer reliability was found to be 0.92 .

\section{STATISTICAL ANALYSIS}

The data were coded and analyzed using the statistical package for social sciences (SPSS) version 16 software. Cross-tabulations and Chi-square statistics were computed.

\section{RESULTS}

Table 1 depicts the distribution of study subjects by age and sex. The study population consisted of 1060 prisoners which included 1025 males and 35 females. One hundred and twenty-five $(96.7 \%)$ of the respondents were males and $35(3.3 \%)$ were females. The study subjects were from the age group of 19 to 74 years. The study subjects

Table 1: Distribution of study subjects by age and sex

\begin{tabular}{llll}
\hline \multirow{2}{*}{ Variables } & & \multicolumn{2}{c}{ Total subjects } \\
\cline { 3 - 4 } Sex & Males & 1025 & $\%$ \\
Age (years) & Females & 35 & 96.7 \\
& $0-24$ & 130 & 3.3 \\
& $25-34$ & 492 & 12.3 \\
& $35-44$ & 267 & 46.4 \\
& $45-54$ & 123 & 25.2 \\
& 55 and above & 48 & 11.6 \\
\hline Total & & 1060 & 4.5 \\
\hline
\end{tabular}

were distributed in the age groups: 24 years and below 130 (12.3\%), 25 to 34 years $492(46.4 \%), 35$ to 44 years 267 (25.2\%), 45 to 54 years $123(11.6 \%)$ and 55 years and above $48(4.5 \%)$. The mean age of the study subjects was 34.6 years.

Table 2 represents distribution of study subjects based on oral mucosal lesions and sex. Among the study subjects, $62.3 \%$ of males and $82.9 \%$ of females were free of any oral mucosal lesions. The prevalence of leukoplakia was $2.2 \%$ among males and $2.9 \%$ among females. Oral submucous fibrosis was observed in $1.4 \%$ of males. Smokers palate was found in $7 \%$ of the male subjects. The prevalence of smokers melanosis was $27.6 \%$ among males and $8.6 \%$ among females. The difference in occurrence of oral mucosal lesions between sex among the study subjects was not statistically significant $(p=0.251)$.

Table 3 demonstrates distribution of study subjects based on oral mucosal lesions and age. The prevalence of leukoplakia was highest among the study subjects of 24 years and below (4.6\%). Thirteen percent of the study subjects of the age group of 55 years and above had oral submucous fibrosis. The prevalence of smokers melanosis was highest among study subjects of 55 years and above. Twenty-nine percent of the study subjects of 55 years and above had smokers palate compared to their counterparts. The difference in occurrence of oral mucosal lesions across different age groups among the study subjects was statistically significant $(\mathrm{p}=0.000)$.

\section{DISCUSSION}

The prison population is unique and challenging with many health problems like hypertension, diabetes, mental disorders including poor oral health. ${ }^{6}$ From the present study, it was revealed that the prevalence of leukoplakia was $2.3 \%$ which is similar to a study conducted in Norway $^{2}$ and higher compared to a study conducted in Bengaluru. ${ }^{7}$ One percent of the inmates in the present

Table 2: Distribution of study subjects based on oral mucosal lesions and sex

\begin{tabular}{|c|c|c|c|c|c|c|c|c|}
\hline \multirow[b]{2}{*}{ Oral mucosal lesions } & \multicolumn{2}{|c|}{ Male $(n=1025)$} & \multicolumn{2}{|c|}{ Female $(n=35)$} & \multicolumn{2}{|c|}{ Total $(n=1060)$} & \multirow[b]{2}{*}{$\chi^{2}$} & \multirow[b]{2}{*}{$p$-value } \\
\hline & $n$ & $\%$ & $n$ & $\%$ & $n$ & $\%$ & & \\
\hline No & 639 & 62.3 & 29 & 82.9 & 668 & 63 & 9.019 & 0.251 \\
\hline Oral cancer & 0 & 0 & 0 & 0 & 0 & 0 & & \\
\hline Leukoplakia & 23 & 2.2 & 1 & 2.9 & 24 & 2.3 & & \\
\hline Lichen planus & 4 & 0.4 & 0 & 0 & 4 & 0.4 & & \\
\hline Ulceration & 10 & 1 & 1 & 2.9 & 11 & 1 & & \\
\hline Acute necrotizing gingivitis & 0 & 0 & 0 & 0 & 0 & 0 & & \\
\hline Candidiasis & 3 & 0.3 & 1 & 2.9 & 4 & 0.4 & & \\
\hline Abscess & 3 & 0.3 & 0 & 0 & 3 & 0.3 & & \\
\hline Oral submucous fibrosis & 14 & 1.4 & 0 & 0 & 14 & 1.3 & & \\
\hline Smokers melanosis & 283 & 27.6 & 3 & 8.6 & 286 & 27 & & \\
\hline Smokers palate & 72 & 7 & 0 & 0 & 72 & 6.8 & & \\
\hline
\end{tabular}

$\chi^{2}$ : Chi-square 
Table 3: Distribution of study subjects based on oral mucosal lesions and age

\begin{tabular}{|c|c|c|c|c|c|c|c|c|c|c|c|c|}
\hline \multirow[b]{2}{*}{ Oral mucosal lesions } & \multicolumn{2}{|c|}{$\begin{array}{c}0-24 \text { years } \\
(n=130)\end{array}$} & \multicolumn{2}{|c|}{$\begin{array}{c}\text { 25-34 years } \\
(n=492)\end{array}$} & \multicolumn{2}{|c|}{$\begin{array}{c}\text { 35-44 years } \\
(n=267)\end{array}$} & \multicolumn{2}{|c|}{$\begin{array}{c}45-54 \text { years } \\
(n=123)\end{array}$} & \multicolumn{2}{|c|}{$\begin{array}{l}55 \text { and above } \\
\text { years }(n=48)\end{array}$} & \multirow[b]{2}{*}{$\chi^{2}$} & \multirow[b]{2}{*}{$p$-value } \\
\hline & $n$ & $\%$ & $n$ & $\%$ & $n$ & $\%$ & $n$ & $\%$ & $n$ & $\%$ & & \\
\hline No & 91 & 70 & 348 & 71 & 159 & 60 & 54 & 43.9 & 16 & 33.3 & 137.5 & 0.000 \\
\hline Oral cancer & 0 & 0 & 0 & 0 & 0 & 0 & 0 & 0 & 0 & 0 & & \\
\hline Leukoplakia & 6 & 4.6 & 12 & 2.4 & 5 & 1.9 & 1 & 0.8 & 0 & 0 & & \\
\hline Lichen planus & 0 & 0 & 2 & 0.4 & 1 & 0.4 & 1 & 0.8 & 0 & 0 & & \\
\hline Ulceration & 1 & 0.8 & 3 & 0.6 & 5 & 1.9 & 2 & 1.6 & 0 & 0 & & \\
\hline Acute necrotizing gingivitis & 0 & 0 & 0 & 0 & 0 & 0 & 0 & 0 & 0 & 0 & & \\
\hline Candidiasis & 0 & 0 & 0 & 0 & 3 & 1.1 & 1 & 0.8 & 0 & 0 & & \\
\hline Abscess & 0 & 0 & 3 & 0.6 & 0 & 0 & 0 & 0 & 0 & 0 & & \\
\hline Oral submucous fibrosis & 0 & 0 & 2 & 0.4 & 2 & 0.7 & 4 & 3.2 & 6 & 12.5 & & \\
\hline Smokers melanosis & 32 & 25 & 117 & 24 & 78 & 29 & 38 & 31 & 21 & 43.8 & & \\
\hline Smokers palate & 0 & 0 & 8 & 1.6 & 21 & 7.9 & 29 & 24 & 14 & 29.2 & & \\
\hline
\end{tabular}

$\chi^{2}$ : Chi-square

study suffered from aphthous ulcer which was similar to the study conducted in Norway ${ }^{2}$ and Bengaluru. ${ }^{7}$ In the present study, $0.4 \%$ of the inmates had Lichen planus lesion in their oral cavity which was found to be low compared to a study conducted in Norway $(2.4 \%)^{2}$ and similar when compared to a study in Bengaluru. ${ }^{7}$ The present findings show that the prevalence of abscess among the study subjects was $0.3 \%$ which is lower compared to a survey conducted in Bengaluru. ${ }^{7}$

Therefore, our findings underscore the importance of providing dental health education in the prison settings, since it seems doubtful whether most prisoners with these problems would receive treatment. Assessment of personal habits among the study subjects would provide a probable reasoning for the development of oral lesions. This was a limitation of the present study.

\section{CONCLUSION}

Important factors to be considered in the differential diagnosis are the history of the lesions, the clinical appearance, location, and symptoms like pain, burning sensation, and discomfort upon deglutition. It is also important to consider the nature of the lesion. An oral mucosal lesion can be reactive, inflammatory, infectious, or malignant. ${ }^{8}$ The present study reveals that a large proportion of the study subjects had oral mucosal lesions. There is an urgent need to intensify efforts in educating both the prisoners and prison officials about the occurrence and prevention of oral mucosal lesions. Tobacco cessation programs should be incorporated at regular intervals in prison settings. Regular oral healthcare services should be included in prisons to restore the oral health of the prisoners. An improvement in oral health will play an integral role in improving the general health of the prison inmates.

\section{REFERENCES}

1. Nobile CGA, Fortunato L, Pavia M, Cantanzaro IAF. Oral health status of male prisoners in Italy. Int Dent J 2007;57(1): 27-35.

2. Hurlen B, Jacobsen N, Hurlen P. Hepatitis B serum markers and oral health in a group of Norwegian male prisoners. Acta Odontol Scand 1984;42(1):53-58.

3. Cuevas FL, Pedraza EL, Rodriguez MC, Badillo RA. Oral mucosal lesions among prisoners at risk of HIV in Mexico. International Conference of AIDS 2002 July;7-12. Available at: www.nlm.nih.gov (Accessed on 22nd January 2010).

4. Walsh T, Tickle M, Milsom K, Buchanan K, Zoitopoulos L. An investigation of the nature of research into dental health in prisons: a systematic review. Br Dent J 2008;204(12):683-689.

5. WHO. Oral Health Survey-Basic Methods, 4th ed. New Delhi: AITBS Publishers; 1999.

6. Heng CK, Morse DE. Dental caries experience of female inmates. J Publ Health Dent 2002;62(1):57-61.

7. Uma SR, Hiremath SS. Oral healthcare for inmates of central prison, Bengaluru: an institutionalized approach. J Ind Assoc Public Health Dentist 2011;17(Suppl 1):297-304.

8. Saini R. Oral lesions: A true clinical indicator in human immunodeficiency virus. J Nat Sc Biol Med 2011;2(2):145-150. 